\title{
4-Aminoantipyrine Analogs as Anti-inflammatory and Antioxidant agents: Synthesis, Biological Evaluation and Molecular Docking Studies
}

\author{
Qazi Yasar*, Zahid Zaheer \\ Department of Pharmaceutical Chemistry, Y. B. Chavan College of Pharmacy, Rauza Bagh, Aurangabad, Maharashtra, INDIA.
}

\begin{abstract}
Objectives: A novel series of 4-aminoantipyrine derivatives were designed and efficiently synthesized from Gewald, triphosgene and various substituted aromatic/ aliphatic/heterocyclic amines. Methods: The synthesized derivatives were characterized by IR, NMR, Mass and elemental analysis. The synthesized derivatives were evaluated for their anti-inflammatory activity using in vitro protein denaturation assay and antioxidant activity by using the 1,1-diphenyl-1-picrylhydrazyl free radical scavenging method. To establish the selectivity and safety profile of the drug, the most active compounds $4 \mathrm{a}$ and $4 \mathrm{~b}$ were further screened for cytotoxicity against HeLa and MCF-7 cell lines using the sulforhodamine-B assay. The synthesized compounds were also analyzed for ADME properties and a docking study was done into the active site of oxidoreductase, cyclooxygenase-1 and cyclooxygenase-2 enzymes in an attempt to understand their binding mode using Auto Dock Vina. Results: Among the series Compounds $4 \mathrm{a}$ and $4 \mathrm{~b}$ showed potent anti-inflammatory activity and antioxidant activity as compared with standard diclofenac and Ascorbic acid respectively. The results of in silico ADME Screening showed that compounds could be exploited as an oral drug candidate.
\end{abstract}

The most prominent compound $4 \mathrm{a}$ and $4 \mathrm{~b}$ showed no significant cytotoxic activity against HeLa and MCF-7 cell lines. The molecular docking study of most active compounds had shown good binding interactions against oxidoreductase, cyclooxygenase-1 and cyclooxygenase-2 enzymes. Conclusion: Results of in vitro anti-inflammatory, antioxidant activities and docking study showed that synthesized compounds had potential antiinflammatory and antioxidant activities and can be further optimized and developed as a lead compound.

Key words: 2-Aminothiophenes, Auto Dock, Cyclooxygenase-1 and Cyclooxygenase-2, Sulforhodamine-B assay, Oxidoreductase.

Correspondence

Mr. Qazi Yasar,

Assistant Professor, Department of Pharmaceutical Chemistry, Y. B. Chavan College of Pharmacy, Rauza Bagh, Aurangabad-431001, Maharashtra, INDIA.

Phone: +91 8668605379

Email: ykkazi@gmail.com

DOI: 10.5530/ijpi.2021.1.4

\section{INTRODUCTION}

In the Nonsteroidal anti-inflammatory drug (NSAID) class, the pyrazolin-5-one scaffold occupies a significant position, has attracted considerable attention from researchers due to its important biological activities. Several pyrazoles, pyrazolin-5-ones and pyrazolidine-3,5-diones have been developed..$^{1-3}$ Interesting anti-inflammatory, analgesic, anti-pyretic, ${ }^{2}$ anti-inflammatory, ${ }^{4}$ anti-diabetic, ${ }^{5}$ anti-oxidant, ${ }^{6}$ anti-, anti-proliferative, ${ }^{7,8}$ antifungal and antimicrobial ${ }^{9}$ effects of these compounds have been identified. Some of them are important drugs with clinical use in the treatment of fever, arthritis, musculoskeletal and joint disorders, such as phenylbutazone, dipyrone, propyfenazone, ramifenazone, suxibuzone. ${ }^{10}$ Phenazone or antipyrine is a well-known compound for its analgesic and antipyretic effects, while its 4 -amino derivative also has anti-inflammatory effects. The pyrazolin-5-one derivatives are known as non-selective inhibitors of cyclooxygenase (COX) isoenzymes that inhibit platelet thromboxane and prostanoid synthesis. ${ }^{11}$

The biological effects of these compounds against reactive species have their scavenging ability against reactive species. During respiration, Reactive Oxygen Species (ROS) produce as a natural byproduct of oxygen metabolism and play important role in human health and development provided they are under control. However, by using enzymes such as superoxide dismutase and catalase, cells can protect against ROS. ${ }^{12,13}$ Nevertheless, for normal cellular function, a balance between the production of ROS and its detoxification is necessary. However, the imbalance can cause damage to the components of cells such as proteins, lipids, sugars and nucleotides, ${ }^{14}$ resulting in oxidative stress induced by the induction of various diseases, such as, ${ }^{15}$ atherosclerosis, ${ }^{16}$ cardiovascular disease, ${ }^{17}$ inflammation, etc. ${ }^{18}$

Many studies revealed that agents with the ability to protect against ROS, synthetic, or naturally occurring are therapeutically successful in the treatment of these diseases. Antipyrine has been shown to have a strong scavenging effect for ROS, especially for hydroxyl radicals, while 4-Aminoantipyrine has shown a higher scavenging ability for oxygen (peroxyl, hydroxyl, superoxide radicals) and also for reactive nitrogen species (nitric oxide, peroxynitrite).$^{19}$ However, apart from the beneficial effects of pyrazoline derivatives, therapy with these reactive nitrogen species (nitric oxide, peroxynitrite) has also been shown. Skin rashes, gastrointestinal pain, cardiovascular (agranulocytosis, blood dyscrasia) complications and renal damage are the most commonly reported side effects. $^{20}$

In recent years, research has focused to improve the safety profile and pharmacological effects of the classical anti-inflammatory drugs by chemical modulation of their structure with various heterocyclic systems such as thiazoles, thiadiazoles, triazoles, pyrimidines and thiophenes. ${ }^{21-24}$ Within this class of heterocyclic compounds, the 2-aminothiophene ring system and their substituted derivatives have attracted a great deal of interest over the years. ${ }^{25}$ Compounds with analgesic, anti-inflammatory, anti-depressant, antioxidant, antiviral, antitumor and other properties were 
also found in the series of thiophene and thienopyrimidine derivatives. ${ }^{26}$ Thus, a molecule carrying more than one pharmacophore, each with a different mode of action, may help treat more than one disease. Based on the facts above, these two heterocyclic moieties are important for antiinflammatory as well as antioxidant activities. Our goal in the present study was to design (Figure 1) and synthesize new antipyrine derivatives with pyrazole moiety coupled with 2-aminothiophenes in the hope of improving anti-inflammatory and antioxidant activities.

\section{MATERIALS AND METHODS}

\section{Chemistry}

All the solvents and reagents were purchased from commercial suppliers and were used without further purification. The progress of the reaction was monitored by thin-layer chromatography (TLC) on silica gel-G pre-coated aluminum plates (Merck) and visualized under ultraviolet (UV) light. Melting points were measured in open capillary tubes and uncorrected. The synthesized compounds were characterized by spectral analysis like ${ }^{1} \mathrm{H}$ NMR, ${ }^{13} \mathrm{C}$ NMR and Mass spectroscopy. The mass spectra were recorded under ESI mode on Waters Micromass equipment (model Q-TOF micro). The NMR spectra were recorded with a Bruker Avance II 400 NMR Spectrometer (Billerica, MA, USA) at $400 \mathrm{MHz}$ Frequency in deuterated DMSO using TMS as internal standard (chemical shift $\delta$ in ppm). Chemical shifts $(\delta)$ are reported in parts per million (ppm). Infrared (IR) spectra were recorded on JASCO FTIR (PS 4000) using a $\mathrm{KBr}$ pellet.

\section{General procedure for the synthesis of ethyl 2-amino-5,6-dihydro-4H-} cyclopenta[b]thiophene-3-carboxylate (1)

Cyclopentanone $(0.1 \mathrm{~mol})$, sulfur $(0.1 \mathrm{~mol})$, ethyl cyanoacetate $(0.1 \mathrm{~mol})$ and ethanol are mixed and stirred together. To this well-stirred solution of diethylamine $(0.125 \mathrm{~mol})$ are added dropwise for $30 \mathrm{~min}$ and stirring continued for another $3 \mathrm{hr}$ at ambient temperature. The reaction mixture was kept in refrigeration overnight. The solid separated was filtered on the next day and washed with $20 \mathrm{ml}$ of chilled $50 \%$ aqueous methanol and dried to get the final compound.

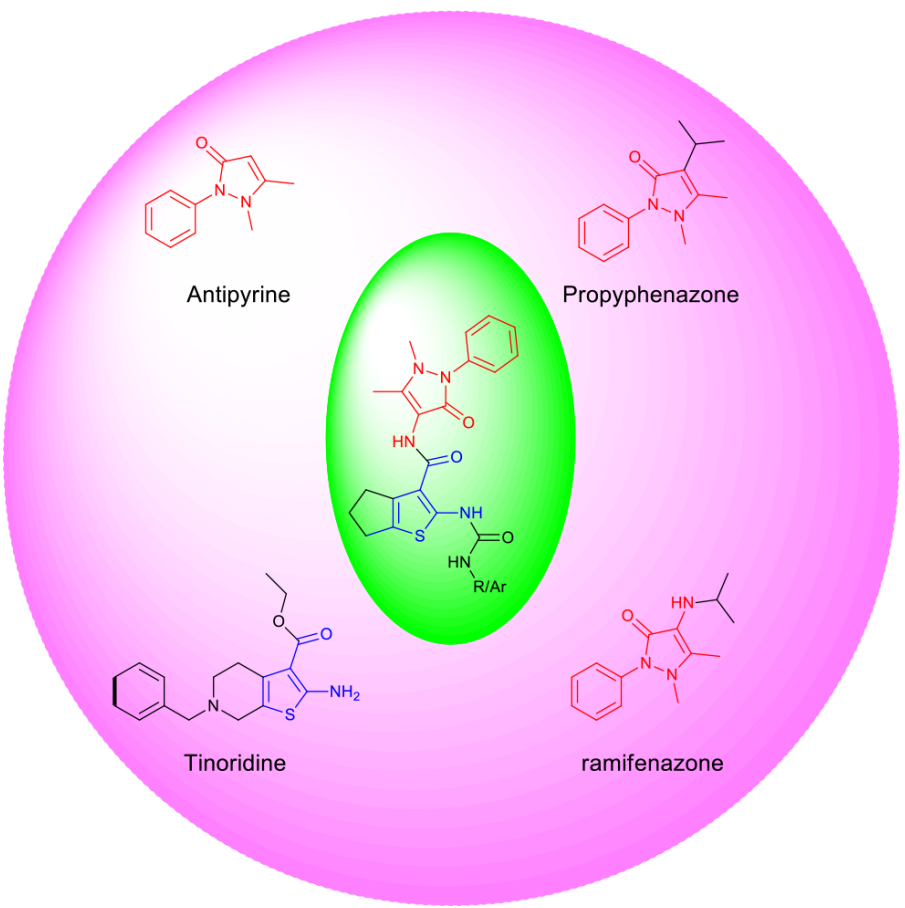

Figure 1: Chemical structure and pharmacophoric pattern of Anti-inflammatory drugs and newly synthesized compound $4 a-i$.
General procedure for the synthesis of 2-amino-N-(1,5-dimethyl-3-oxo2-phenyl-2,3-dihydro-1H-pyrazol-4-yl)-5,6-dihydro-4H-cyclopenta[b] thiophene-3-carboxamide (3)

2-amino-5,6-dihydro-4H-cyclopenta[b]thiophene-3-carboxylate (1) $(0.005 \mathrm{~mol})$ and 4-Amino antipyrine (2) $(0.005 \mathrm{~mol})$ was transferred independently in $100 \mathrm{ml} \mathrm{RBF}$. To this solution, $15 \mathrm{ml}$ methanol was added and refluxed for $2-3 \mathrm{hrs}$ at $60-70^{\circ} \mathrm{C}$. Completion of the reaction was monitored by TLC. After completion of the reaction, the mixture was poured on crushed ice and stirred. The product was precipitated out and it was filtered and dried. Recrystallized from ethanol to obtained pure compounds 3 .

General procedure for the synthesis of 2-(Substitutedcarboxamido)$\mathrm{N}$-(1,5-dimethyl-3-oxo-2-phenyl-2,3-dihydro-1H-pyrazol-4-yl)-4,5,6,7tetrahydrobenzo[b]thiophene-3-carboxamide $(4 a-i)$

A mixture of triphosgene ( 0.1 mole) and aromatic/aliphatic/heterocyclic amines $(0.1 \mathrm{~mole})$ was transferred to $100 \mathrm{~mL} \mathrm{RBF}$, to this 1,4 -dioxane was added and stirred. The reaction mixture was refluxed at $60-70^{\circ} \mathrm{C}$ for 2.5- 3.0 h. The flask was removed, cooled and filtered if particles were seen. To the solution/filtrate 2-amino-N-(1,5-dimethyl-3-oxo2-phenyl-2,3-dihydro-1H-pyrazol-4-yl)-5,6-dihydro-4H-cyclopenta [b]thiophene-3-carboxamide (3) was added and refluxed for $2 \mathrm{~h}$. The excess of 1,4-dioxane was removed by rotary distillation under reduced pressure. To the residue remaining in the flask, $50 \%$ aqueous alcoholic $\mathrm{KOH}$ solution was added and refluxed for another $3 \mathrm{~h}$. The content of the flask was poured on ice and neutralized with conc. $\mathrm{HCl}$. The separated product was filtered, dried and recrystallized from ethanol. Physical Characterization data was given in Table 1.

$\mathrm{N}$-(1,5-dimethyl-3-oxo-2-phenyl-2,3-dihydro-1H-pyrazol-4-yl)2-(3-methylureido)-5,6-dihydro-4H-cyclopenta[b]thiophene-3carboxamide (4a)

m.p. $188-190^{\circ} \mathrm{C}$; IR (KBr, cm $\left.{ }^{-1}\right)$ : 3012(Ar.C-H), 2985 (C-CH); 1690 $(\mathrm{C}=\mathrm{O}), 3328(\mathrm{~N}-\mathrm{H}),. 1419(\mathrm{Ar}-\mathrm{C}=\mathrm{C}), 1144(\mathrm{C}-\mathrm{N}), 1211(\mathrm{C}-\mathrm{O}) ;{ }^{1} \mathrm{H}$ NMR $\left(400 \mathrm{MHz}, \mathrm{DMSO}-d_{6}\right) \delta 7.53-7.46(\mathrm{~m}, 1 \mathrm{H}), 7.38-7.31(\mathrm{~m}, 2 \mathrm{H}), 3.73$ $(\mathrm{t}, J=5.7 \mathrm{~Hz}, 1 \mathrm{H}), 2.85(\mathrm{t}, J=5.2 \mathrm{~Hz}, 1 \mathrm{H}), 2.39-2.31(\mathrm{~m}, 1 \mathrm{H}), 2.18$ $(\mathrm{s}, 1 \mathrm{H}) ;{ }^{13} \mathrm{C}$ NMR (DMSO- $\left.d_{6}\right) \delta 163.56,162.64,156.15,153.84,141.40$, $135.64,135.33,134.90,129.23,126.88,123.62,111.57,107.99,36.89$, 29.89, 29.00, 27.09, 27.01, 11.29; MS m/z: 426.16 [M+1]; Anal. Calcd. For $\mathrm{C}_{21} \mathrm{H}_{23} \mathrm{~N}_{5} \mathrm{O}_{3} \mathrm{~S}$ : C, 59.28; H, 5.45; N, 16.46; O, 11.28; S, 7.54\%. Found: C, 59.18; H, 5.41; N, 16.39; O, 11.31; S, 7.44\%

$\mathrm{N}$-(1,5-dimethyl-3-oxo-2-phenyl-2,3-dihydro-1H-pyrazol-4-yl)2-(3-ethylureido)-5,6-dihydro-4H-cyclopenta[b]thiophene-3carboxamide (4b)

m.p. $198-199^{\circ} \mathrm{C}$; IR (KBr, cm $\left.{ }^{-1}\right)$ : 3019(Ar.C-H), 2875 (C-CH); 1680 (C=O), 3328(N-H.), 1429(Ar C=C), 1144(C-N), 1231 (C-O); ${ }^{1} \mathrm{H}$ NMR $(400 \mathrm{MHz}$, DMSO-d $) \delta 7.53-7.46(\mathrm{~m}, 1 \mathrm{H}), 7.38-7.31(\mathrm{~m}, 2 \mathrm{H}), 3.73(\mathrm{t}$, $\mathrm{J}=5.7 \mathrm{~Hz}, 1 \mathrm{H}), 3.20(\mathrm{q}, \mathrm{J}=6.1 \mathrm{~Hz}, 1 \mathrm{H}), 2.85(\mathrm{t}, \mathrm{J}=5.2 \mathrm{~Hz}, 1 \mathrm{H}), 2.39-$ $2.31(\mathrm{~m}, 1 \mathrm{H}), 2.18(\mathrm{~s}, 1 \mathrm{H}), 1.22(\mathrm{t}, \mathrm{J}=6.2 \mathrm{~Hz}, 2 \mathrm{H}) ;{ }^{13} \mathrm{C}$ NMR $\left(\right.$ DMSO-d $\left._{6}\right)$ $\delta 163.56,162.64,155.34,153.70,141.40,135.64,135.33,134.90,129.23$, $126.88,123.62,111.61,107.99,36.89,34.19,29.89,29.00,27.09,15.17$, 11.29; MS m/z: $440.17[\mathrm{M}+1]$; Anal. Calcd. For $\mathrm{C}_{22} \mathrm{H}_{25} \mathrm{~N}_{5} \mathrm{O}_{3} \mathrm{~S}: \mathrm{C}, 60.12$; H, 5.73; N, 15.93; O, 10.92; S, 7.30\%. Found: C, 60.08; H, 5.68; N, 15.97; O, $10.89 ; \mathrm{S}, 7.31 \%$

$\mathrm{N}$-(1,5-dimethyl-3-oxo-2-phenyl-2,3-dihydro-1H-pyrazol-4-yl)-2(3,3-dimethylureido)-5,6-dihydro-4H-cyclopenta[b]thiophene-3carboxamide (4c)

m.p. $154-156^{\circ} \mathrm{C}$; IR (KBr, cm $\left.{ }^{-1}\right)$ : 3102(Ar.C-H), 2926 (C-CH); 1681 (C=O), 3330 (N-H.), 1399 (Ar C=C), 1144 (C-N), 1198 (C-O); 1H NMR $\left(400 \mathrm{MHz}, \mathrm{DMSO}-\mathrm{d}_{6}\right) \delta 7.53-7.46(\mathrm{~m}, 1 \mathrm{H}), 7.38-7.31(\mathrm{~m}, 2 \mathrm{H}), 3.73$ $(\mathrm{t}, \mathrm{J}=6.0 \mathrm{~Hz}, 1 \mathrm{H}), 3.10(\mathrm{~s}, 1 \mathrm{H}), 2.88-2.82(\mathrm{~m}, 1 \mathrm{H}), 2.35(\mathrm{p}, \mathrm{J}=5.6 \mathrm{~Hz}$, 
$1 \mathrm{H}), 2.18(\mathrm{~s}, 1 \mathrm{H}) ;{ }^{13} \mathrm{C}$ NMR (DMSO-d $) \delta 163.56,162.64,154.25,154.05$, $141.40,135.73,135.33,134.97,129.23,126.88,123.62$, 111.39, 107.99, $36.89,36.38,29.89,29.00,27.09,11.29$; MS m/z: $440.17[\mathrm{M}+1]$; Anal. Calcd. For $\mathrm{C}_{22} \mathrm{H}_{25} \mathrm{~N}_{5} \mathrm{O}_{3} \mathrm{~S}$ : C, 60.12; H, 5.73; N, 15.93; O, 10.92; S, 7.30\%. Found: C, 60.19; H, 5.76; N, 15.90; O, 10.99; S, 7.33\%

2-(3,3-diethylureido)- $\mathrm{N}$-(1,5-dimethyl-3-oxo-2-phenyl-2,

3-dihydro-1H-pyrazol-4-yl)-5,6-dihydro-4H-cyclopenta

[b] thiophene-1-carboxamide (4d)

m.p. $162-163^{\circ} \mathrm{C}$; IR (KBr, cm $\left.{ }^{-1}\right): 3069$ (Ar.C-H), 2865 (C-CH); 1677 (C=O), 3402 (N-H.), 1419 (Ar C=C), $1144(\mathrm{C}-\mathrm{N}), 1181$ (C-O); ${ }^{1} \mathrm{H}$ NMR $(400 \mathrm{MHz}$, DMSO-d $) \delta 7.53-7.46(\mathrm{~m}, 1 \mathrm{H}), 7.38-7.31(\mathrm{~m}, 2 \mathrm{H}), 3.73$ $(\mathrm{t}, \mathrm{J}=5.7 \mathrm{~Hz}, 1 \mathrm{H}), 3.37(\mathrm{q}, \mathrm{J}=7.0 \mathrm{~Hz}, 2 \mathrm{H}), 2.85(\mathrm{t}, \mathrm{J}=5.2 \mathrm{~Hz}, 1 \mathrm{H}), 2.39-$ $2.31(\mathrm{~m}, 1 \mathrm{H}), 2.18(\mathrm{~s}, 1 \mathrm{H}), 1.13(\mathrm{t}, \mathrm{J}=7.0 \mathrm{~Hz}, 3 \mathrm{H}) ;{ }^{13} \mathrm{C}$ NMR $\left(\mathrm{DMSO}^{\left.-\mathrm{d}_{6}\right)}\right.$ $\delta 163.56,162.64,154.96,153.99,141.40,135.73,135.33,134.97,129.23$, $126.88,123.62,111.40,107.99,41.32,36.89,29.89,29.00,27.09,13.14$, 11.29; MS m/z: $468.20[\mathrm{M}+1]$; Anal. Calcd. For $\mathrm{C}_{24} \mathrm{H}_{29} \mathrm{~N}_{5} \mathrm{O}_{3} \mathrm{~S}: \mathrm{C}$ C, 61.65; H, 6.25; N, 14.98; O, 10.27; S, 6.86\%. Found: C, 61.64; H, 6.26; N, 14.95; $\mathrm{O}, 10.21 ; \mathrm{S}, 6.89 \%$
$\mathrm{N}$-(3-((1,5-dimethyl-3-oxo-2-phenyl-2,3-dihydro-1H-pyrazol-4-yl) carbamoyl)-5,6-dihydro-4H-cyclopenta[b]thiophen-2-yl)piperidine-1carboxamide (4e)

m.p. 162-163 ${ }^{\circ} \mathrm{C}$; IR (KBr, cm $\left.{ }^{-1}\right)$ : 3069 (Ar.C-H), 2865 (C-CH); 1677 $(\mathrm{C}=\mathrm{O}), 3402(\mathrm{~N}-\mathrm{H}),$.1419 (Ar C=C), 1144(C-N), $1181(\mathrm{C}-\mathrm{O}) ; 1 \mathrm{H}$ NMR $\left(400 \mathrm{MHz}, \mathrm{DMSO}-d_{6}\right) \delta 7.53-7.46(\mathrm{~m}, 1 \mathrm{H}), 7.38-7.31(\mathrm{~m}, 2 \mathrm{H}), 3.73(\mathrm{t}$, $J=5.7 \mathrm{~Hz}, 1 \mathrm{H}), 3.37$ (q, J=7.0 Hz, 2H), $2.85(\mathrm{t}, J=5.2 \mathrm{~Hz}, 1 \mathrm{H}), 2.39-$ $2.31(\mathrm{~m}, 1 \mathrm{H}), 2.18(\mathrm{~s}, 1 \mathrm{H}), 1.13(\mathrm{t}, J=7.0 \mathrm{~Hz}, 3 \mathrm{H}) ;{ }^{13} \mathrm{C}$ NMR $\left(\right.$ DMSO- $\left.d_{6}\right)$ $\delta 163.56,162.64,154.96,153.99,141.40,135.73,135.33,134.97,129.23$, $126.88,123.62,111.40,107.99,41.32,36.89,29.89,29.00,27.09,13.14$, 11.29; MS m/z: 468.20 [M+1]; Anal. Calcd. For $\mathrm{C}_{24} \mathrm{H}_{29} \mathrm{~N}_{5} \mathrm{O}_{3} \mathrm{~S}: \mathrm{C}$ C, 61.65 ; $\mathrm{H}, 6.25$; N, 14.98; O, 10.27; S, 6.86\%. Found: C, 61.64; H, 6.26; N, 14.95; $\mathrm{O}, 10.21 ; \mathrm{S}, 6.89 \%$

$\mathrm{N}$-(3-((1,5-dimethyl-3-oxo-2-phenyl-2,3-dihydro-1H-pyrazol-4-yl) carbamoyl)-5,6-dihydro-4H-cyclopenta[b]thiophen-2-yl) piperazine-1-carboxamide (4f)

m.p. 266-268 ${ }^{\circ} \mathrm{C}$; IR (KBr, cm $\left.{ }^{-1}\right): 3077$ (Ar.C-H), 2973 (C-CH); 1687 $(\mathrm{C}=\mathrm{O}), 3378(\mathrm{~N}-\mathrm{H}),. 1419(\operatorname{Ar} \mathrm{C}=\mathrm{C}), 1094(\mathrm{C}-\mathrm{N}), 1231(\mathrm{C}-\mathrm{O})$; 1H NMR

Table 1: Physical characterization and elemental analysis of compounds 4a-i.

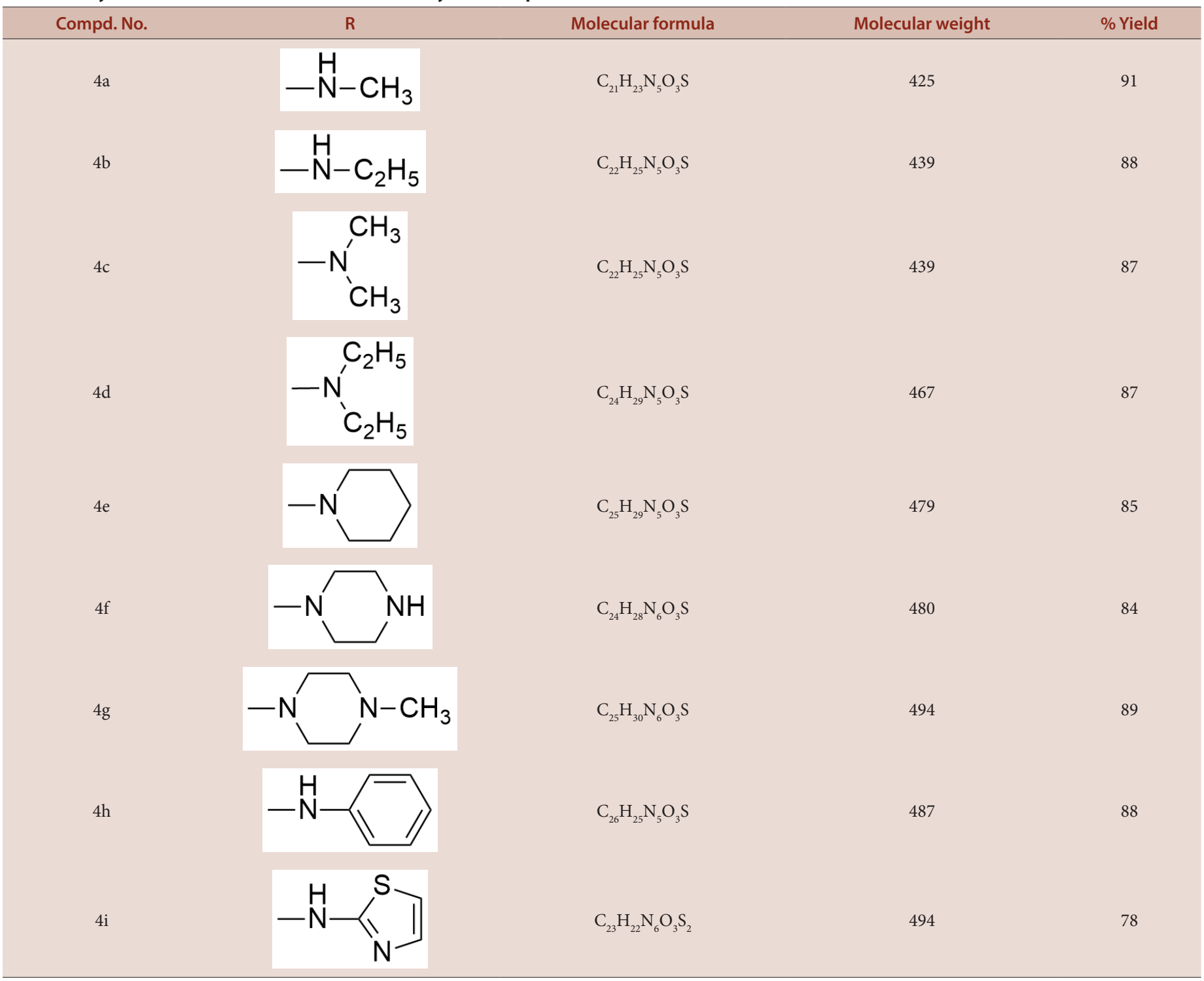


$\left(400 \mathrm{MHz}, \mathrm{DMSO}-d_{6}\right) \delta 7.53-7.47(\mathrm{~m}, 2 \mathrm{H}), 7.38-7.31(\mathrm{~m}, 2 \mathrm{H}), 3.73$ $(\mathrm{t}, J=5.9 \mathrm{~Hz}, 2 \mathrm{H}), 3.41(\mathrm{~d}, J=8.5 \mathrm{~Hz}, 1 \mathrm{H}), 3.10(\mathrm{~s}, 3 \mathrm{H}), 2.97-2.92$ $(\mathrm{m}, 3 \mathrm{H}), 2.86(\mathrm{~d}, J=5.5 \mathrm{~Hz}, 1 \mathrm{H}), 2.35(\mathrm{p}, J=5.5 \mathrm{~Hz}, 2 \mathrm{H}), 2.18(\mathrm{~s}, 3 \mathrm{H})$; ${ }^{13} \mathrm{C}$ NMR (DMSO- $\left.d_{6}\right) \delta 163.56,162.64,154.97,154.03,141.40,135.89$, $135.33,134.94,129.23,126.88,123.62,111.43,107.99,45.55,45.19$, 36.89, 29.89, 29.00, 27.09, 11.29; MS m/z: 481.20 [M+1]; Anal. Calcd. For $\mathrm{C}_{24} \mathrm{H}_{28} \mathrm{~N}_{6} \mathrm{O}_{3} \mathrm{~S}$ : C C, 59.98; H, 5.87; N, 17.49; O, 9.99; S, $6.67 \%$. Found: C, 59.93; H, 5.88; N, 17.48; O, 9.98; S, $6.62 \%$

N-(3-((1,5-dimethyl-3-oxo-2-phenyl-2,3-dihydro-1H-pyrazol-4-yl) carbamoyl)-5,6-dihydro-4H-cyclopenta[b]thiophen-2-yl)-4methylpiperazine-1-carboxamide (4g)

m.p. 220-222 ${ }^{\circ} \mathrm{C}$; IR (KBr, cm $\left.{ }^{-1}\right)$ : 3082(Ar.C-H), 2991 (C-CH); 1690 $(\mathrm{C}=\mathrm{O}), 3328(\mathrm{~N}-\mathrm{H}),. 1419(\mathrm{Ar} \mathrm{C}=\mathrm{C}), 1150(\mathrm{C}-\mathrm{N}), 1220(\mathrm{C}-\mathrm{O}) ; 1 \mathrm{H}$ NMR $\left(400 \mathrm{MHz}, \mathrm{DMSO}-d_{6}\right) \delta 7.53-7.43(\mathrm{~m}, 4 \mathrm{H}), 7.39-7.29(\mathrm{~m}, 6 \mathrm{H}), 7.10$ $(\mathrm{td}, J=7.2,1.7 \mathrm{~Hz}, 1 \mathrm{H}), 3.73(\mathrm{t}, J=5.9 \mathrm{~Hz}, 2 \mathrm{H}), 2.85(\mathrm{~d}, J=11.0 \mathrm{~Hz}, 1 \mathrm{H})$, 2.35 (p, $J=5.5 \mathrm{~Hz}, 2 \mathrm{H}$ ), $2.18(\mathrm{~s}, 3 \mathrm{H}) ;{ }^{13} \mathrm{C}$ NMR (DMSO- $\left.d_{6}\right) \delta 163.56$, $162.64,154.90,154.03,141.40,135.89,135.33,134.94,129.23,126.88$, $123.62,111.43,107.99,53.37,45.06,44.82,36.89,29.89,29.00,27.09$, 11.29; MS m/z: $495.21[\mathrm{M}+1]$; Anal. Calcd. For $\mathrm{C}_{25} \mathrm{H}_{30} \mathrm{~N}_{6} \mathrm{O}_{3} \mathrm{~S}: \mathrm{C}, 60.71$; H, 6.11; N, 16.99; O, 9.70; S, 6.48 \%. Found: C, 60.74; H, 6.13; N, 16.98; $\mathrm{O}, 9.71 ; \mathrm{S}, 6.44 \%$

$\mathrm{N}$-(1,5-dimethyl-3-oxo-2-phenyl-2,3-dihydro-1H-pyrazol-4-yl)2-(3-phenylureido)-5,6-dihydro-4H-cyclopenta[b]thiophene-3carboxamide (4h)

m.p. 188-190 C; IR (KBr, cm+): 3062(Ar.C-H), $2995(\mathrm{C}-\mathrm{CH}) ; 1690$ $(\mathrm{C}=\mathrm{O}), 3365(\mathrm{~N}-\mathrm{H}),$.1426 (Ar C=C), 1223(C-N), 1201 (C-O); 1H NMR $\left(400 \mathrm{MHz}, \mathrm{DMSO}-d_{6}\right) \delta 7.57-7.46(\mathrm{~m}, 3 \mathrm{H}), 7.38-7.31(\mathrm{~m}, 3 \mathrm{H}), 7.24$ $(\mathrm{d}, J=4.6 \mathrm{~Hz}, 1 \mathrm{H}), 3.73(\mathrm{t}, J=5.7 \mathrm{~Hz}, 2 \mathrm{H}), 2.85(\mathrm{t}, J=5.2 \mathrm{~Hz}, 2 \mathrm{H})$, $2.39-2.31(\mathrm{~m}, 2 \mathrm{H}), 2.18(\mathrm{~s}, 2 \mathrm{H}) ;{ }^{13} \mathrm{C}$ NMR $\left(\mathrm{DMSO}-d_{6}\right) \delta 163.55,162.64$, $153.99,153.41,141.40,138.72,135.78,135.33,134.97,129.23,129.05$, $126.88,123.62,123.40,119.06,111.74,107.99,36.89,29.89,29.00,27.09$, 11.29; MS m/z: $488.17[\mathrm{M}+1]$; Anal. Calcd. For $\mathrm{C}_{26} \mathrm{H}_{25} \mathrm{~N}_{5} \mathrm{O}_{3} \mathrm{~S}: \mathrm{C}, 64.05$; H, 5.17; N, 14.36; O, 9.84; S, 6.58 \%. Found: C, 64.09; H, 5.18; N, 14.35; $\mathrm{O}, 9.83 ; \mathrm{S}, 6.56 \%$

N-(1,5-dimethyl-3-oxo-2-phenyl-2,3-dihydro-1H-pyrazol-4-yl)-2(3-(thiazol-2-yl)ureido)-5,6-dihydro-4H-cyclopenta[b]thiophene-3carboxamide (4i)

m.p. 278-280 ${ }^{\circ}$; IR $\left(\mathrm{KBr}, \mathrm{cm}^{-1}\right)$ : 3059 (Ar.C-H), $2985(\mathrm{C}-\mathrm{CH}) ; 1669$ (C=O), 3390 (N-H.), 1409(Ar C=C), 1130 (C-N), 1218 (C-O); 1H NMR $\left(400 \mathrm{MHz}, \mathrm{DMSO}-d_{6}\right) \delta 7.57-7.46(\mathrm{~m}, 3 \mathrm{H}), 7.38-7.31(\mathrm{~m}, 3 \mathrm{H}), 7.24$ $(\mathrm{d}, J=4.6 \mathrm{~Hz}, 1 \mathrm{H}), 3.73(\mathrm{t}, J=5.7 \mathrm{~Hz}, 2 \mathrm{H}), 2.85(\mathrm{t}, J=5.2 \mathrm{~Hz}, 2 \mathrm{H})$, $2.39-2.31(\mathrm{~m}, 2 \mathrm{H}), 2.18(\mathrm{~s}, 2 \mathrm{H}) ;{ }^{13} \mathrm{C}$ NMR (DMSO- $\left.d_{6}\right) \delta 163.55,162.64$, $160.59,153.98,153.89,141.40,135.73,135.33,135.29,134.97,129.23$, $126.88,123.62,112.05,111.74,107.99,36.89,29.89,29.00,27.09,11.29$; MS m/z: 495.12 [M+1]; Anal. Calcd. For $\mathrm{C}_{23} \mathrm{H}_{22} \mathrm{~N}_{6} \mathrm{O}_{3} \mathrm{~S}_{2}: \mathrm{C}, 55.85 ; \mathrm{H}, 4.48$; N, 16.99; O, 9.70; S, 12.97\%. Found: C, 55.89; H, 4.43; N, 16.98; O, 9.73; S, $12.99 \%$

\section{Biological Evaluation}

In vitro anti-inflammatory activity by protein denaturation method

The in vitro protein denaturation assay ${ }^{27,28}$ was used with minor modifications to test the anti-inflammatory effects of the synthesized compounds. A volume of $1 \mathrm{ml}$ of synthetic derivatives at various concentrations $(25,50,75$ and $100 \mu \mathrm{g} / \mathrm{ml})$ was homogenized with $1 \mathrm{ml}$ of bovine serum albumin aqueous solution (5 percent) Then the mixtures were incubated at $\left(37 \pm 2^{\circ} \mathrm{C}\right)$ in an incubator for $15 \mathrm{~min}$ and heated at $70^{\circ} \mathrm{C}$ for $5 \mathrm{~min}$. After cooling, the absorbance was measured at $660 \mathrm{~nm}$ for each mixture. Diclofenac sodium was used as a reference standard at $1 \mathrm{mM}$ and the control tube was a mixture of distilled water and BSA.
Each test was performed in triplicate. The percentage inhibition of protein denaturation calculated by using the following formula:

$$
\text { Percentage of inhibition (\%) } \left.=\left(A_{\text {Blank }}-A_{\text {sample }}\right) / A_{\text {Blank }}\right) \times 100
$$

Where, $\mathrm{A}_{\text {Blank }}=$ absorbance of the blank reaction, $\mathrm{A}_{\text {Sample }}=$ absorbance of the test compounds. The $\mathrm{IC}_{50}$ value was calculated from the graph plotted between $\%$ inhibition and synthesized derivatives.

\section{In vitro antioxidant assay}

Antioxidant activity was evaluated spectrophotometrically by using the free radical scavenging method. The hydrogen atom or electron donation ability of some compounds was measured from the bleaching of the purple-colored methanol solution of 1,1-diphenyl-1-picrylhydrazyl (DPPH). The spectrophotometric assay uses the stable radical DPPH as a reagent. DPPH solution $(3 \mu \mathrm{g} / \mathrm{ml})$ was prepared in methanol. The solution of methanol and DPPH (1:1) was used for blank reference. 4 dilutions of different concentrations $(25 \mu \mathrm{g} / \mathrm{ml}, 50 \mu \mathrm{g} / \mathrm{ml}, 75 \mu \mathrm{g} / \mathrm{ml}$ and $100 \mu \mathrm{g} / \mathrm{ml})$ of each test compound and standard (ascorbic acid) were prepared in the methanol and $1 \mathrm{ml}$ of each concentration was added to $1 \mathrm{ml}$ of DPPH solution. After vigorous shaking, the reaction mixture was placed in a dark place for $30 \mathrm{~min}$ at room temperature and their absorbance was measured at $517 \mathrm{~nm} .{ }^{29}$ Percentage (\%) inhibition of free radical DPPH was calculated as follows:

$$
\left.\% \text { Inhibition }=\left(A_{\text {Blank }}-A_{\text {sample }}\right) / A_{\text {Blank }}\right) \times 100
$$

Where, $A_{\text {Blank }}=$ absorbance of the blank reaction, $A_{\text {Sample }}=$ absorbance of the test compounds. The $\mathrm{IC}_{50}$ value was calculated from the graph plotted between $\%$ inhibition and synthesized derivatives.

\section{In vitro Cytotoxicity Study}

The toxicity study of the synthesized compounds at the early stage of research simplifies the path to clinical trials and reduces the failure of potential therapeutics at later stages of testing. ${ }^{30}$ In vitro cytotoxicity tests of the most active compounds $4 \mathrm{a}$ and $4 \mathrm{~b}$ were performed against HeLa (human cervical cell line) and MCF-7 (human breast cell lines) by SRB (sulforhodamine B) assay using Adriamycin as a positive control to explore the selectivity and safety profile of the synthesized compounds. ${ }^{31}$ The viability and growth in the presence of test material is calculated by using the following formula:

$$
\% \text { Cytotoxicity }=\frac{\text { Average of control }- \text { Average of compound }}{\text { Average of control }- \text { Average of blank }} \times 100
$$

Where control is the culture medium with cells and DMSO and blank is the culture medium without cells. This assay gives growth inhibition concentration $\left(\mathrm{GI}_{50}\right)$ value, which was taken as the minimum concentration of the compound killing $50 \%$ of the cells.

\section{Molecular docking study Protein preparation}

The Crystal structure of oxidoreductase (PDB: 1MBT), ${ }^{32} \mathrm{COX}-1$ (PDB: $3 \mathrm{KK} 6),{ }^{33,34}$ and COX-2 (PDB: 3LN1) ${ }^{35}$ crystal structures have been obtained from the Protein Data Bank http://www.rcsb.org. And Polar hydrogen was added. Gasteiger partial charges should be allocated to each atom. Then, the final protein structure was saved in the pdbqt format.

\section{Ligand design}

One of the most important determinants for effective docking is the structure of ligands, so pre-analysis of the structures of ligands is most important. Drugs such as ligand properties were confirmed by the manual 
application of the Rule of Five of Lipinski and used for further studies. To draw the structure of the ligands (4a-i), Chem and Bio Draw 12.0 was used. The ligands were cleaned in 2D and further energy minimized in 3D by the MM2 parameters and force field of the Chem and Bio 3D 12.0 documentation. Original ionization states were preserved and the $3 \mathrm{D}$ structures were used to assess chiralities. All the structures were written in mol2 file format and finally converted into PDB format. AutoDock requires that ligands for each atom give partial atomic charges and types of AutoDock atoms; it also requires a description of the ligands' rotatable bonds. AutoDock relies on the idea of a tree in which the 'root' is the rigid core of the molecule and the 'branches' extending from the root are flexible portions. Therefore pdbqt format was used for ligands, which were recognized by AutoDock. AutoDock allows fully flexible modeling of specific portions of the receptor, like that of ligands. In the present study, the binding site was selected based on the amino acid residues, which were involved in binding with oxidoreductase, COX-1 and COX2 enzymes obtained from Protein Data Bank. The grid was centered at the region including amino acid residues that surround the active sites. To find the conformers with the lowest binding energy, the Lamarckian Genetic Algorithm (LGA) was used based on an optimization algorithm. Finally, the docking task was performed using EasyDockVina v2.0 (GUI of AutoDock Vina. EasyDockVina is a tool to perform multiple receptor-ligand docking with AutoDockVina. It uses AutoDock Vina for performing docking, it also uses MGLtools and open babel for the preparation of molecules. The results of molecular docking studies were obtained in output files in the form of estimated free energy bindings $(\mathrm{kcal} / \mathrm{mol})$ and inhibition constant $(\mathrm{Ki}$ in $\mu \mathrm{M})$ at $298.15 \mathrm{~K}$ temperature. For visualization and analyses of docking results, pymol, Discovery studio and Protein-ligand interaction profiler were used, which explored hydrogen, hydrophobic and van der Waals contacts.

\section{ADME prediction}

For the prediction of ADME properties, a computational study of synthesized compounds $4 \mathrm{a}-\mathrm{i}$ was carried out. partition coefficient logarithm (miLog P), molecular weight (MW), Molecular volume (MV), hydrogen bond donor number (n-OHNH), hydrogen bond acceptor number (n-ON), number of rotatable bonds (n-ROTB), topological polar surface area (TPSA) and Lipinski's rule of five were measured using the Molinspiration online property calculation toolkit. Absorption (\% ABS) was determined by applying formula: $\%$ ABS $=109-(0.345 \times$ TPSA $) .{ }^{36}$

\section{RESULTS}

The procedure for the synthesis of the designed compounds $4 \mathrm{a}-\mathrm{i}$ is illustrated in Scheme (Figture 2). As per the scheme, gewald (1), 4-Aminontipyrine (2) and $15 \mathrm{ml}$ methanol was refluxed for $2-3 \mathrm{hrs}$ at $60-70^{\circ} \mathrm{C}$ to yield the open-chain urea derivative (3) as an intermediate. This reaction mixture was treated with stirring a 1:1 mixture of substituted anilines and triphosgene in 1,4-dioxane and was refluxed for 2-3h to afford final compounds (4a-i).

A total of nine antipyrine (4a-i) derivatives were synthesized following this synthetic protocol. The yields of synthesized novel compounds were in the range of $78-91 \%$. Melting points were determined in open capillary tubes and are uncorrected. The physical data for the compounds are presented in Table 1 . The synthesized compounds were characterized by $\mathrm{IR},{ }^{1} \mathrm{H} \mathrm{NMR},{ }^{13} \mathrm{C}$ NMR, mass spectral analysis and elemental analysis.

\section{In vitro anti-inflammatory activity}

All the synthesized compounds were evaluated for anti-inflammatory activity by protein denaturation method (Table 2). The results of the anti-inflammatory activity showed that all the compounds exhibited good to moderate anti-inflammatory activity. The results were expressed as percentage inhibition of protein denaturation. The result reveals that

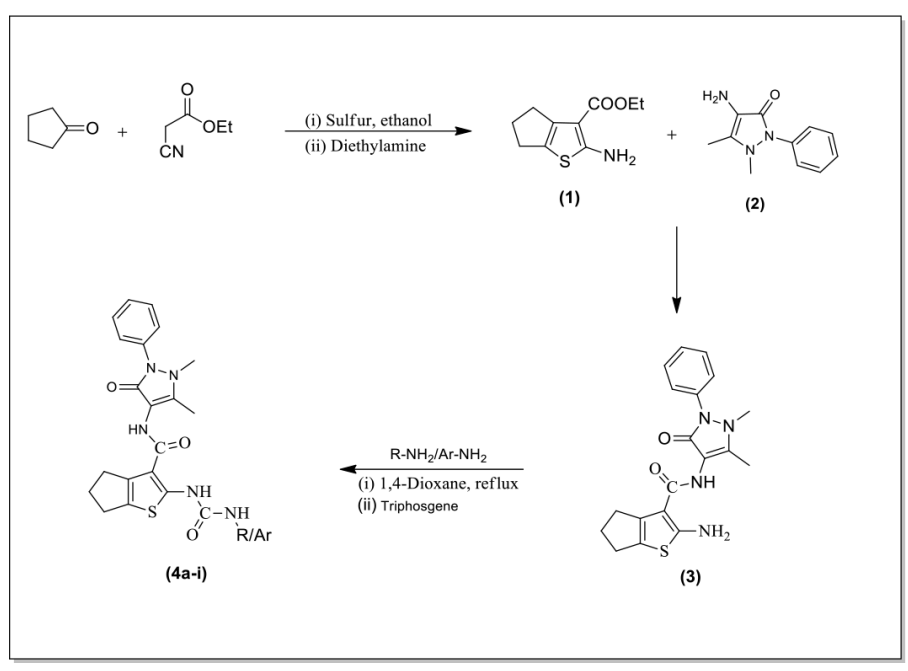

Figure 2: Scheme for the synthesis of titled compounds $4(\mathrm{a}-\mathrm{i})$.

Table 2: Anti-inflammatory activity of the synthesized derivatives (4a-i).

\begin{tabular}{|c|c|c|c|c|c|}
\hline \multirow{2}{*}{ Compound } & \multicolumn{4}{|c|}{$\%$ inhibition (Protein denaturation) } & \multirow{2}{*}{$\mathrm{IC}_{50}(\mu \mathrm{g} / \mathrm{mL})$} \\
\hline & $25 \mu \mathrm{g} / \mathrm{mL}$ & $50 \mu \mathrm{g} / \mathrm{mL}$ & $75 \mu \mathrm{g} / \mathrm{mL}$ & $100 \mu \mathrm{g} / \mathrm{mL}$ & \\
\hline $4 a$ & $42.01 \pm 0.50$ & $57.80 \pm 0.58$ & $65.20 \pm 0.25$ & $74.10 \pm 0.47$ & $38.98 \pm 0.98$ \\
\hline $4 b$ & $32.17 \pm 1.02$ & $44.60 \pm 1.10$ & $57.18 \pm 0.37$ & $67.97 \pm 0.19$ & $61.62 \pm 0.52$ \\
\hline $4 c$ & $28.01 \pm 2.19^{*}$ & $42.13 \pm 0.79$ & $53.90 \pm 0.54$ & $64.29 \pm 0.28^{\star \star}$ & $68.60 \pm 0.58$ \\
\hline $4 d$ & $29.80 \pm 0.79$ & $41.20 \pm 0.12$ & $53.20 \pm 0.41$ & $64.27 \pm 0.45$ & $68.85 \pm 0.27$ \\
\hline $4 e$ & $35.50 \pm 2.01$ & $47.89 \pm 0.44^{* *}$ & $59.37 \pm 0.12$ & $69.20 \pm 0.84$ & $55.91 \pm 0.42$ \\
\hline $4 \mathrm{f}$ & $23.20 \pm 0.11^{*}$ & $37.69 \pm 0.54$ & $49.21 \pm 0.25^{\star *}$ & $60.18 \pm 0.45$ & $77.81 \pm 0.87^{* *}$ \\
\hline $4 g$ & $39.25 \pm 0.59$ & $47.65 \pm 0.21$ & $59.60 \pm 0.29$ & $71.67 \pm 0.89$ & $52.20 \pm 0.50$ \\
\hline $4 \mathrm{~h}$ & $41.23 \pm 0.31$ & $55.87 \pm 0.38$ & $62.19 \pm 0.36$ & $71.99 \pm 0.51$ & $42.71 \pm 0.71$ \\
\hline $4 \mathbf{i}$ & $30.17 \pm 0.47$ & $42.30 \pm 0.99$ & $52.19 \pm 0.52$ & $62.45 \pm 0.15$ & $70.21 \pm 0.31$ \\
\hline Diclofenac & $44.69 \pm 0.55$ & $65.20 \pm 0.33$ & $74.90 \pm 0.12$ & $81.50 \pm 0.22$ & $28.04 \pm 0.15$ \\
\hline
\end{tabular}

All assays were carried out in triplicate. All data were analyzed by analysis of variance followed by Dunnett's multiple comparison test for $n=3:{ }^{*} P \leq 0.05 ;{ }^{*} P, 0.01$. The percentage values was calculated from the Eq. 1 . Lower $\mathrm{IC}_{50}$ values indicate higher Anti-inflammatory activity. 
compounds $4 \mathrm{a}$ has shown the highest inhibition $\left(\mathrm{IC}_{50}=38.98 \mu \mathrm{g} / \mathrm{mL}\right)$ as compared with standard diclofenac sodium $\left(\mathrm{IC}_{50}=28.04 \mu \mathrm{g} / \mathrm{mL}\right)$, whereas compounds $4 \mathrm{e}, 4 \mathrm{~g}$ and $4 \mathrm{~h}$ displayed good inhibition.

\section{In vitro antioxidant assay}

Newly synthesized derivatives were evaluated for their in vitro antioxidant activity by DPPH assay. The percentage (\%) inhibition was calculated from Eq. 1 and the $\mathrm{IC}_{50}$ value of newly synthesized compounds was obtained from the graph drawn between \% inhibition v/s concentrations of test compounds. The results reveal that all the newly synthesized compounds had shown good to moderate antioxidant activity. Compound $4 \mathrm{~b}$ had shown excellent antioxidant activity with $\mathrm{IC}_{50}$ values of $45.7 \mu \mathrm{g} / \mathrm{mL}$ compared to ascorbic acid as a standard drug. Whereas $4 \mathrm{a}, 4 \mathrm{~h}$ and $4 \mathrm{i}$ compounds showed good inhibition. The results were summarized in Table 3 .

\section{In vitro Cytotoxicity Study}

The cytotoxicity of the most promising compounds $4 \mathrm{a}$ and $4 \mathrm{~b}$ was evaluated against the two human cell lines, HeLa (Human cervical cell line) and MCF7 (human breast cell line) using Sulforhodamine B (SRB) assay using Adriamycin as a positive control. The observed results are summarized in Table 4. The cytotoxic effect of these compounds was checked on cell lines using the concentration between the ranges of $100 \mu \mathrm{g} / \mathrm{ml}$ to $0.50 \mu \mathrm{g} /$ $\mathrm{ml}$ to find the $100 \%$ growth inhibition value $\left(\mathrm{GI}_{50}\right)$. The results indicated that, in SRB cytotoxicity studies, the synthesized compounds $4 \mathrm{a}$ and $4 \mathrm{~b}$ have shown no significant cell toxicity against HeLa and MCF-7 cell lines as shown in Table 4 . Hence the compounds $4 \mathrm{a}$ and $4 \mathrm{~b}$ can be developed as safer and selective anti-inflammatory agents.

\section{Molecular docking study}

The Crystal structure of oxidoreductase (PDB: 1MBT), COX-1 (PDB: 3KK6) and COX-2 (PDB: 3kk6) were obtained from the Protein Data Bank http://www.rcsb.org. To predict possible binding interactions, the proposed ligands $(4 \mathrm{a}-\mathrm{i})$ were docked into the receptors of oxidoreductase (PDB: 1MBT) and COX-1 and COX 2 by using AutoDock 1.5.6. The grid was prepared at the region including amino acid residues that surround the active sites. The results were expressed in terms of estimated free binding energies $(\mathrm{kcal} / \mathrm{mol})$ as shown in Table 5 and represented in Figure 3.

\section{In silico ADME prediction}

The in silico ADME prediction of the synthesized compounds $4 \mathrm{a}-\mathrm{i}$ was performed using Molinspiration online property calculation toolkit (http://www.molinspiration.com/cgi-bin/properties 2014) and the results are provided in Table 6 . All synthesized antipyrine derivatives have a good \% ABS ranging from $71.03-78.51 \%$. Also, none of the synthesized compounds violated the Lipinski rule of five, thus showing good druglike properties. A molecule likely to be developed as an orally active drug candidate should not violate more than one of the following four criteria: molecular weight $\leq 500$, miLogP (octanol-water partition coefficient) $\leq$ 5 , number of hydrogen bond donors $\leq 5$ and number of hydrogen bond acceptors $\leq 10$. All the compounds $4 \mathrm{a}-\mathrm{I}$ follow the criteria for orally active drug and therefore, these compounds may have good potential as oral agents for subsequent development.

Table 4: IC50 values of tested compounds against MCF-7 and HeLa cell lines.

\begin{tabular}{ccc}
\hline \multirow{2}{*}{ Compound No. } & \multicolumn{2}{c}{${ }^{\mathrm{a}}{ }{ }_{50}(\mu \mathrm{g} / \mathrm{mL})$} \\
\cline { 2 - 3 } & MCF7 & HeLa \\
\hline 4a & $>100$ & $>100$ \\
4b & $>100$ & $>100$ \\
Adriamycin & 0.5 & 0.35 \\
\hline
\end{tabular}

${ }^{\mathrm{a}} \mathrm{GI}_{50}$ is the concentration exhibiting $50 \%$ inhibition of the growth as compared to the growth of control. HeLa (Human cervical cell line) and MCF7 (human breast cell line) All assays were carried out in triplicate. The percentage values was calculated from the Eq. 3.

Table 5: Interaction energies of compounds 4a-i and standard drugs with the Oxidoreductase, COX-1, and COX-2 enzymes.

\begin{tabular}{cccc}
\hline \multirow{2}{*}{ Compound } & \multicolumn{3}{c}{ Binding Energy $(\mathrm{kcal} / \mathrm{mol})$} \\
\cline { 2 - 4 } & 1MBT & 3KK6 & 3LN1 \\
\hline $\mathbf{4 a}$ & -9.5 & -9 & -8.7 \\
$\mathbf{4 b}$ & -8.6 & -8.7 & -8.4 \\
$\mathbf{4 c}$ & -8.5 & -8.7 & -8.1 \\
$\mathbf{4 d}$ & -8.7 & -8.8 & -8.1 \\
$\mathbf{4} \mathbf{e}$ & -8.3 & -9.6 & -8.6 \\
$\mathbf{4 f}$ & -8 & -9.3 & -7.8 \\
$\mathbf{4 g}$ & -8.4 & -9.1 & -8.5 \\
$\mathbf{4 h}$ & -7.4 & -9.5 & -8.6 \\
$\mathbf{4 i}$ & -8.3 & -8.9 & -8.6 \\
celecoxib & - & -8.2 & -8.2 \\
Ascorbic acid & -7.7 & - & - \\
\hline
\end{tabular}

Lower binding energy values indicate a higher docking score

Table 3: Antioxidant activities of the synthesized derivatives (4a-i).

\begin{tabular}{|c|c|c|c|c|c|}
\hline \multirow{2}{*}{ Compound } & \multicolumn{4}{|c|}{$\%$ inhibition (Scavenging activity) } & \multirow{2}{*}{$\mathrm{IC}_{50}(\mu \mathrm{g} / \mathrm{mL})$} \\
\hline & $25 \mu \mathrm{g} / \mathrm{mL}$ & $50 \mu \mathrm{g} / \mathrm{mL}$ & $75 \mu \mathrm{g} / \mathrm{mL}$ & $100 \mu \mathrm{g} / \mathrm{mL}$ & \\
\hline $4 a$ & $35.65 \pm 0.21$ & $51.23 \pm 0.41$ & $65.38 \pm 0.33$ & $78.00 \pm 0.51$ & $49.18 \pm 0.97$ \\
\hline $4 \mathrm{~b}$ & $36.62 \pm 0.54$ & $54.63 \pm 0.56$ & $67.82 \pm 0.42$ & $82.63 \pm 0.42$ & $45.70 \pm 0.32$ \\
\hline $4 c$ & $23.02 \pm 0.69$ & $39.65 \pm 0.31$ & $56.32 \pm 0.25^{\star}$ & $70.23 \pm 0.71$ & $66.77 \pm 0.25$ \\
\hline 4d & $21.68 \pm 0.37$ & $38.91 \pm 0.28$ & $56.74 \pm 0.32$ & $70.73 \pm 0.81^{\star *}$ & $67.69 \pm 0.68$ \\
\hline $4 e$ & $21.03 \pm 0.38^{*}$ & $33.65 \pm 0.39$ & $48.56 \pm 0.16$ & $75.62 \pm 0.29$ & $69.91 \pm 0.79^{* *}$ \\
\hline $4 \mathrm{f}$ & $25.32 \pm 0.27$ & $30.56 \pm 0.57$ & $52.36 \pm 0.28^{* *}$ & $67.23 \pm 0.38$ & $72.9 \pm 0.25$ \\
\hline $4 \mathrm{~g}$ & $15.63 \pm 0.21$ & $32.63 \pm 0.24$ & $44.65 \pm 0.50$ & $66.65 \pm 0.21$ & $77.35 \pm 0.31$ \\
\hline $4 \mathrm{~h}$ & $33.21 \pm 0.37$ & $48.62 \pm \mathrm{d} 0.84^{*}$ & $64.65 \pm 0.27$ & $81.62 \pm 0.54$ & $51.61 \pm 0.20$ \\
\hline $4 \mathbf{i}$ & $32.47 \pm 0.75$ & $47.61 \pm 0.99$ & $64.92 \pm 0.91^{* *}$ & $78.52 \pm 0.34$ & $53.12 \pm 0.17$ \\
\hline Ascorbic acid & $36.41 \pm 0.19$ & $55.91 \pm 0.24$ & $67.6 \pm 0.58$ & $84.94 \pm 0.68$ & $44.68 \pm 0.10$ \\
\hline
\end{tabular}

All assays were carried out in triplicate. All data were analyzed by analysis of variance followed by Dunnett's multiple comparison test for $n=3:{ }^{\star} P$ $\leq 0.05 ;{ }^{*} P, 0.01$. The percentage values was calculated from the Eq. 2 . Lower $\mathrm{IC}_{50}$ values indicate higher radical scavenging activity. 


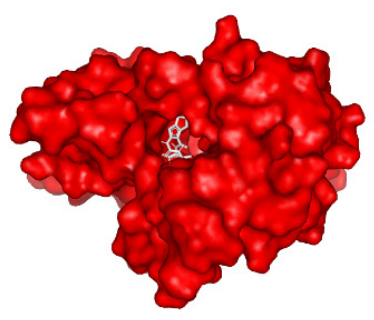

$\mathbf{A}$

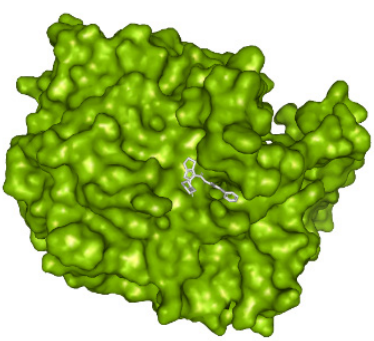

E

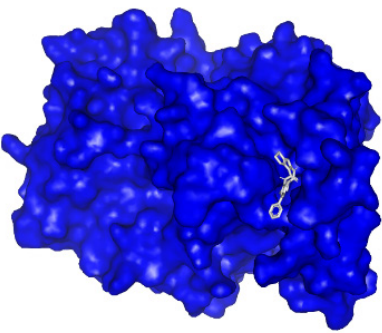

I

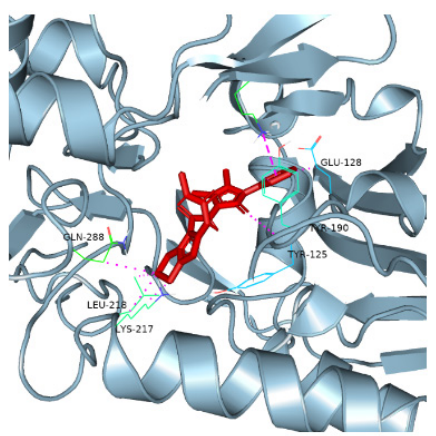

B

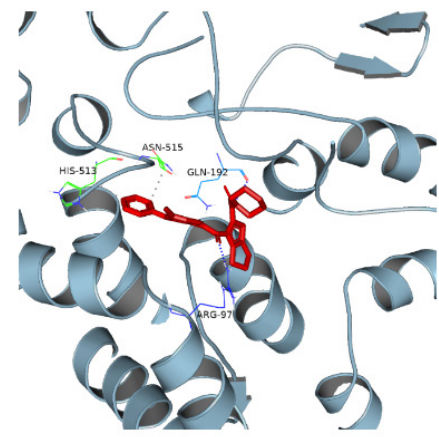

F

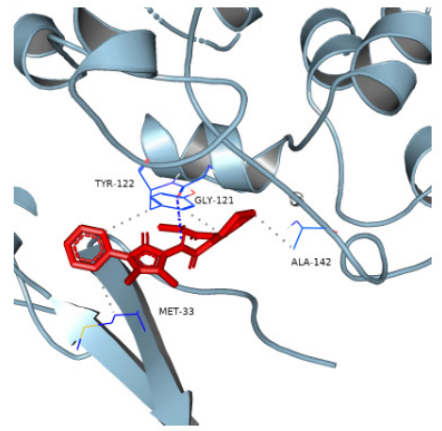

J

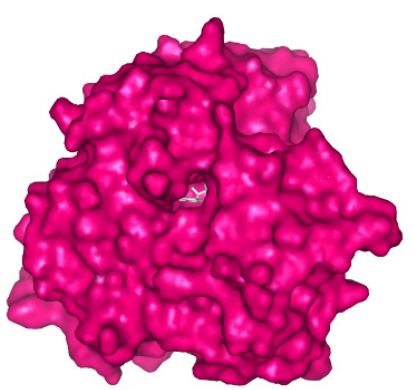

C

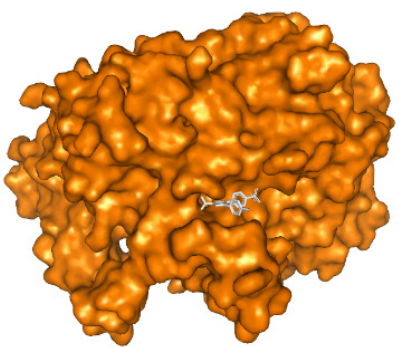

G

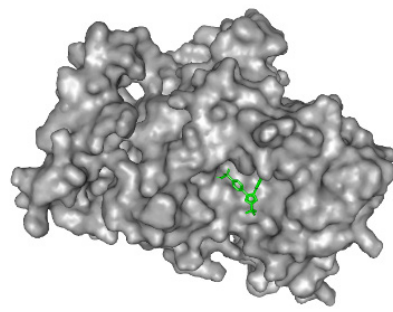

K

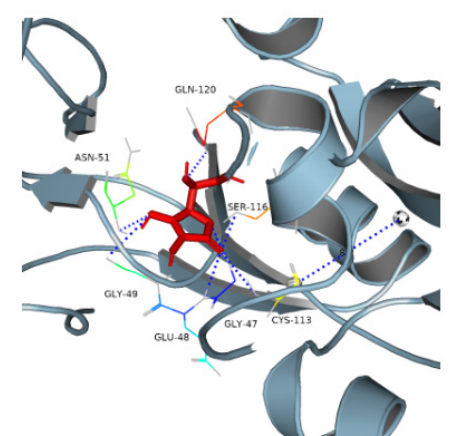

D

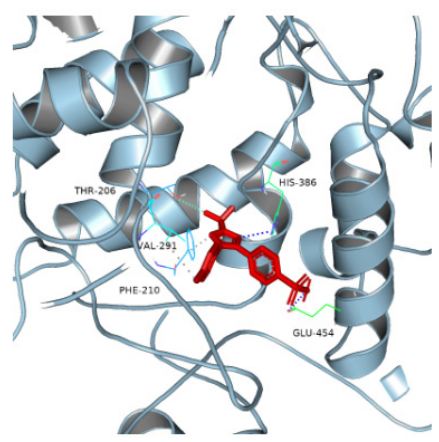

H

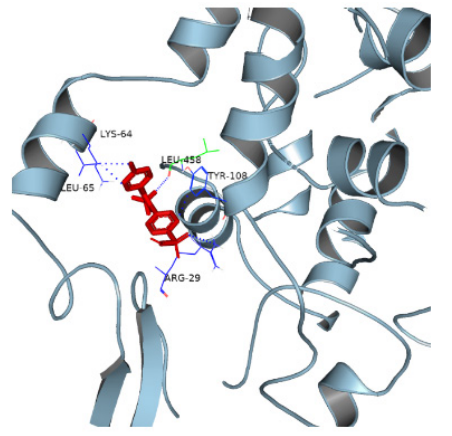

L

Figure 3: Binding modes of ligands and receptors by molecular docking simulation. Docking pose (A) and surface representation (B) of compound 4a and oxidoreductase (1MBT). Docking pose (C) and surface representation (D) of standard drug ascorbic acid and oxidoreductase (1MBT). Docking pose (E) and surface representation (F) of compound 4e and COX-1 (3KK6). Docking pose (G) and surface representation (H) of standard drug Celecoxib and COX-1 (3KK6). Docking pose (I) and surface representation (J) of compound 4a and COX-2 (3LN1). Docking pose (K) and surface representation (L) of standard drug Celecoxib and COX-2 (3LN1). Graphics generated with PyMol.

Table 6: Pharmacokinetic parameters important for good oral bioavailability.

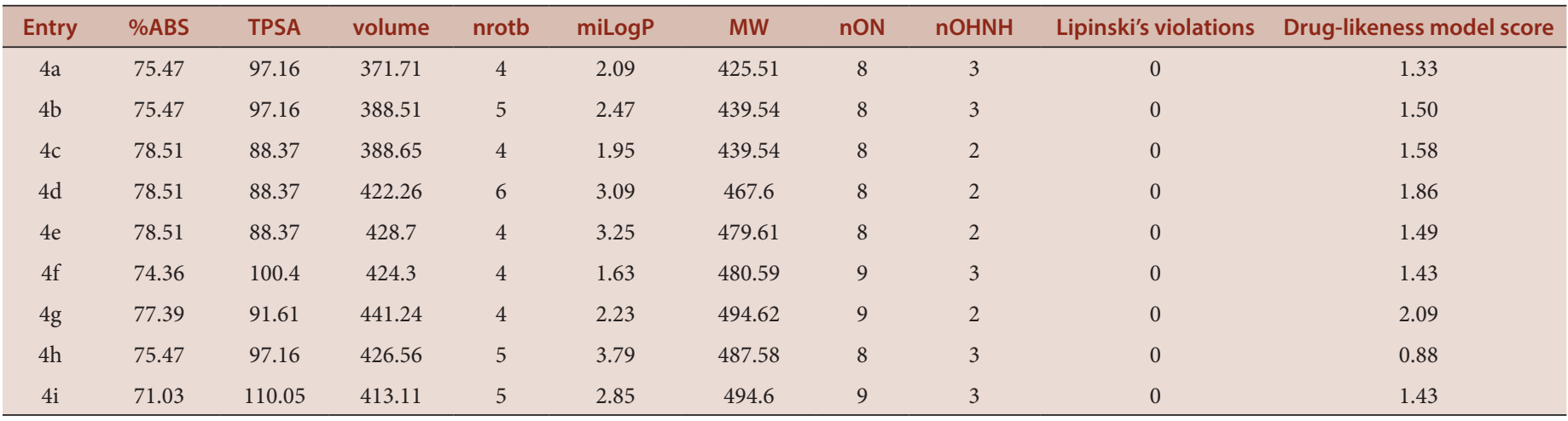




\section{Statistical Analysis}

All assays were carried out in triplicate. Statistical analyses were performed using GraphPad Prism Software. Data were expressed as means \pm SEM. All data were analyzed by analysis of variance followed by Dunnett's multiple comparison test for $n=3:{ }^{*} P \leq 0.05 ;{ }^{*} P, 0.01$.

\section{DISCUSSION}

Pyrazolone derivatives such as antipyrine, dipyrone and aminopyrine are well known compounds used mainly as analgesic, anti-inflammatory and antipyretic drugs and their pharmacological molecular mechanism has been extensively studied. ${ }^{37}$ Several derivatives of antipyrine were also biologically evaluated and analgesic, ${ }^{38}$ anti-inflammatory, ${ }^{39}$ antimicrobial, ${ }^{40}$ and anticancer activity ${ }^{41-43}$ have been reported. All the titled compounds were designed and synthesized by reaction between 4-Aminoantipyrine, Gewald $^{44}$ and various amines. All the reactions were monitored throughout by TLC. All the structures of final compounds were confirmed by IR, NMR and mass spectrometry.

The synthesized 4-Aminoantipyrine analogs were screened for their in vitro anti-inflammatory activity using protein denaturation assay. Diclofenac was used as standard drug for comparison. The title compounds were also evaluated for their antioxidant activity by DPPH assay using Ascorbic acid as standard drug. The results revealed that synthesized compounds showed excellent anti-inflammatory activity and compound $4 \mathrm{a}$ was found to be most active compound suggesting that substitution of a simple methyl group on amine will responsible for this action. However, compounds bearing piperidine (4e), $\mathrm{N}$-methylpiperazine (4g) and aniline rings (4h) were found to be next most active compounds in the series. Compounds having piperazine ring (4f) and thiazole ring (4i) are less active than other compounds of the series. While compound $4 \mathrm{~b}$ was found to be most potent antioxidant, suggested that substitution of ethyl group on amine will responsible for this action. However, compounds bearing methyl group (4a), aniline rings (4h) and thiazole ring (4i) were found to be next most active antioxidant compounds. Similarly Compounds having piperazine ring (4f) and N-metyhlpiperazine (4g) are less active than other compounds of the series. Cytotoxicity study of the most potent compounds $4 \mathrm{a}$ and $4 \mathrm{~b}$ were evaluated on cell growth in cell lines. In vitro cytotoxicity of the most potent compounds $4 \mathrm{a}$ and $4 \mathrm{~b}$ was assessed on a panel of 2 human cell lines (HeLa and MCF7) using SRB assay for measuring cellular proliferation. Each concentration was tested in triplicate in a single experiment. $\mathrm{GI}_{50}$ values were calculated using regression analysis by plotting the percentage survival versus concentrations. The results indicated that, in SRB cytotoxicity studies, most active compounds $4 \mathrm{a}$ and $4 \mathrm{~b}$ shown no significant cell toxicity against HeLa and MCF7 cell lines at the maximum concentration evaluated.

In drug-receptor interaction study ligands were ranked according to docking score/estimated free energy of binding. Molecular docking studies indicated that estimated free energy of binding of docked ligand ranged between -7.4 to -9.5 for oxidoreductase, -8.7 to -9.6 for COX-1 and -7.8 to -8.7 for COX-2 enzymes respectively. Further analyses of results showed that methyl amine substituted derivative (4a) shown the highest affinity with binding energy $-9.5 \mathrm{kcal} / \mathrm{mol}$ towards oxidoreductase, interacting with amino acid residues TYR125, GLU128, TYR190, LYS217, LEU218 and GLN288 compared with standard Ascorbic acid with binding energy $-5.7 \mathrm{kcal} / \mathrm{mol}$ and interacting amino acid residues such as GLY47, GLU48, GLY49, ASN51, SER116 and GLN120. In contrast, piperidine substituted derivative (4e) was found to have highest affinity with binding energy $-9.6 \mathrm{kcal} / \mathrm{mol}$ towards COX-1, interacting with amino acid residues like ARG97, GLN192, HIS513 and ASN515 compared with standard Celecoxib with binding energy $-8.2 \mathrm{kcal} / \mathrm{mol}$ and interacting amino acid residues such as
THR206, PHE210, VAL291, HIS386 and GLU454. While methyl amine substituted derivative (4a) was found to have highest affinity with binding energy $-9.6 \mathrm{kcal} / \mathrm{mol}$ towards COX-2, interacting with amino acid residues like MET33, GLY121, TYR122 and ALA142 (Figure 3) compared with standard Celecoxib with binding energy -8.2 $\mathrm{kcal} / \mathrm{mol}$ and interacting amino acid residues such as ARG29, LYS64, LEU65, TYR108 and LEU458. The in silico ADME prediction of the synthesized compounds showed that all synthesized antipyrine derivatives have a good \% ABS ranging from 71.03-78.51\%. In addition, none of the synthesized compounds violated the Lipinski rule of five, ${ }^{45}$ thus showing good drug-like properties. All the compounds $4 \mathrm{a}-\mathrm{i}$ follows the criteria for orally active drug and therefore, these compounds may have good potential as oral agents for subsequent development.

\section{CONCLUSION}

In conclusion, a novel 2-Aminothiophene coupled Antipyrine derivatives 4(a-i) were designed and synthesized. The structures of the synthesized compounds were confirmed using different spectroscopic techniques. The synthesized compounds were evaluated for their anti-inflammatory and antioxidant activities. The anti-inflammatory activity of the final products was performed using in vitro protein denaturation assay. The result reveals that Most of the compounds showed remarkably good antiinflammatory activity $\left(\mathrm{IC}_{50}\right.$ range $\left.=38.98-77.81 \mu \mathrm{g} / \mathrm{mL}\right)$. The remaining compounds have shown moderate activity. Compound $4 \mathrm{a}$ was found to be the most active compound $\left(\mathrm{IC}_{50}\right.$ value $=38.98 \mu \mathrm{g} / \mathrm{mL}$ ), when compared with the standard drug Diclofenac $\left(\mathrm{IC}_{50}\right.$ value $\left.=28.04 \mu \mathrm{g} / \mathrm{mL}\right)$. Based on antioxidant activity data, compounds $4 \mathrm{~b}$ was found to be the most potent $\left(\mathrm{IC}_{50}\right.$ value $\left.=45.7 \mu \mathrm{g} / \mathrm{mL}\right)$ as compared to the standard drug Ascorbic acid $\left(\mathrm{IC}_{50}\right.$ value $\left.=44.68 \mu \mathrm{g} / \mathrm{mL}\right)$. Furthermore, the cytotoxicity study of the most potent compounds $4 \mathrm{a}$ and $4 \mathrm{~b}$ revealed that compounds did not show any significant cytotoxicity against MCF7 and HeLa cell lines at the maximum concentration evaluated, thus indicating its selectivity in anti-inflammatory action. Further, the docking studies of synthesized compounds with different receptors such as oxidoreductase, COX-1 and COX-2 protein showed good binding interactions and formed various hydrophobic interactions with active site residues. Thus, suggesting that the compounds from the present series can be further optimized and developed as a lead molecule.

\section{ACKNOWLEDGEMENT}

The authors are thankful to Mrs. Fatma Rafiq Zakaria, Chairman of Maulana Azad Educational Trust and Dr. Abubakar Bawazir, I/C Principal of Y. B. Chavan College of Pharmacy, Dr. Rafiq Zakaria Campus, Aurangabad 431001 (M.S.), India for providing the laboratory facility.

\section{CONFLICT OF INTEREST}

The authors declare no conflict of interest.

\section{ABBREVIATIONS}

TLC: Thin Layer Chromatography; MP: Melting Point; IR: Infrared; UV: Ultraviolet; NMR: Nuclear Magnetic Resonance; MS: Mass Spectroscopic; CHN: Carbon hydrogen and nitrogen; FTIR: Fourier-transform infrared spectroscopy; KBr: Potassium bromide; H1NMR: Hydrogen-1 NMR; CdCl: Cadmium Chloride; DMSO: Dimethyl Sulfoxide; PDB: Protein DATA Bank; \% ABS: Absorption; MV: molecular volume; MW: molecular weight; miLog P: logarithm of partition coefficient; $\mathbf{n}-\mathbf{O N}$ : number of hydrogen bond acceptors; n-OHNH: number of hydrogen bond donors; TPSA: topological polar surface area; n-ROTB: number of rotatable bonds. 


\section{REFERENCES}

1. Jamwal A, Javed A, Bhardwaj V. A review on pyrazole derivatives of pharmacological potential. J Pharm BioSci. 2013;3:114-23.

2. El-Hawash S, Badawey ES, El-Ashmawey I. Nonsteroidal anti-inflammatory agents-part 2. Anti-inflammatory, analgesic and antipyretic activity of some substituted 3-pyrazolin-5-ones and 1,2,4,5,6,7-3H-hexahydroindazol-3-ones. Eur J Med Chem. 2006;41(2):155-65.

3. Le Bourdonnec B, Meulon E, Yous S, Goossens JF, Houssin R, Henichart JP. Synthesis and pharmacological evaluation of new pyrazolidine-3,5-diones as AT1 angiotensin II receptor antagonists. J Med Chem. 2000;43(14):2685-97.

4. El-Sayed MA, Abdel-Aziz NI, Abdel-Aziz AA, El-Azab AS, ElTahir KE. Synthesis, biological evaluation and molecular modeling study of pyrazole and pyrazoline derivatives as selective COX-2 inhibitors and anti-inflammatory agents. Bioorg Med Chem. 2012;20(10):3306-16.

5. Fushimi N, Fujikura $H$, Shiohara $H$, Teranishi $H$, Shimizu $K$, Yonekubo $S$, et al. Structure-activity relationship studies of 4-benzyl-1H-pyrazol-3-yl $\beta$-D-glucopyranoside derivatives as potent and selective sodium-glucose co-transporter 1 (SGLT1) inhibitors with therapeutic activity on postprandial hyperglycemia. Bioorg Med Chem. 2012;20(22):6598-612.

6. Khalil NA, Ahmed EM, El-Nassan HB, Ahmed OK, Al-Abd AM. Synthesis and biological evaluation of novel pyrazoline derivatives as anti-inflammatory and antioxidant agents. Arch Pharm Res. 2012;35(6):995-1002.

7. Shamsuzzaman KH, Mashrai A, Sherwani A, Owais M, Siddiqui N. Synthesis and anti-tumor evaluation of B-ring substituted steroidal pyrazoline derivatives. Steroids. 2013;78(12-13):1263-1272.

8. Markovic V, Eric S, Stanojkovic T, Gligorijevic N, Arandelovic S, Todorovic $\mathrm{N}$, et al. Ant proliferative activity and QSAR studies of a series of new 4-aminomethylidene derivatives of some pyrazol-5-ones. Bioorg Med Chem Lett. 2011;21(15):4416-21.

9. Hassan SY. Synthesis, antibacterial and antifungal activity of some new pyrazoline and pyrazole derivatives. Molecules. 2013;18(3):2683-711.

10. Marella A, Ali MR, Alam MT, Saha R, Tanwar O, Akhter M, et al. Pyrazolines: A biological review. Mini Rev Med Chem. 2013;13(6):921-31.

11. Mahle F, Guimaraes T, Meira AV, Correa R, Cruz R, Cruz AB, et al. Synthesis and biological evaluation of $\mathrm{N}$-antipyrine-4-substituted amino-3-chloromaleimide derivatives. Eur J Med Chem. 2010;45(11):4761-8.

12. Abid MR, Schoots IG, Spokes KC, Wu SQ, Mawhinney C, Aird WC. Vascular endothelial growth factor-mediated induction of manganese superoxide dismutase occurs through redox-dependent regulation of forkhead and IB/NF-B. J Bio Chem. 2004;279(42):44030-8.

13. Schiavone JR, Hassan HM. The role of redox in the regulation of manganesecontaining superoxide dismutase biosynthesis in Escherichia coli. J Biol Chem. 1988;263(9):4269-73.

14. Braughler JM, Duncan LA, Chase RL. The involvement of iron in lipid peroxidation. Importance of ferric to ferrous ratios in initiation. J Biol Chem. 1986;261(22):10282-9

15. Lamson DW, Brignall MS. Antioxidants in therapy: Their actions and interactions with oncologic therapies. Altern Med Rev. 1999;4:304-29.

16. Gey KF. Prospects for the prevention of free radical disease, regarding and cardiovascular disease. Bibl Nutr Dieta. 1986;37:53-91.

17. Vivekananthan DP, Penn MS, Sapp SK, Hsu A. Use of antioxidant vitamins for the prevention of cardiovascular disease: A meta-analysis of randomized trials. E J Topol Lancet. 2003:361(9374):2017-23.

18. Ziakas GN, Rekka EA, Gavalas AM, Eleftheriou PT, Kourounakis PN. New analogs of butylated hydroxytoluene as anti-inflammatory and antioxidant agents. Bioorg Med Chem. 2006;14(16):5616-24

19. Mariappan G, Saha BP, Bhuyan NR, Bharti PR, Kumar D. Evaluation of antioxidan potential of pyrazolone derivatives. J Adv Pharm Technol Res. 2010;1(2):260-7.

20. Praveen RPN, Kabir SN, Mohamed T. Nonsteroidal anti-inflammatory drugs (NSAIDS): Progress in small molecule drug development. Pharmaceuticals. 2010;3(5):1530-49

21. Rostom SAF, El-Ashmawy IM, Razik HAAE, Badr MH, Ashour HMA. Design and synthesis of some thiazolyl and thiadiazolyl derivatives of antipyrine as a potential non-acidic anti-inflammatory, analgesic and antimicrobial agents. Bioorg Med Chem. 200;17(2):882-95.

22. Prasada A, Nimavat KS, Vyas KB. Synthesis and biological activity of thiazolidinone containing heterocyclic compound. J Chem Pharm Res. 2012;4:2959-63.

23. Bazrak H, Demirbas A, Demirbas N, Karaoglu SA. Cyclization of some carbothioamide derivatives containing antipyrine and triazole moieties and investigation of their antimicrobial activities. Eur J Med Chem. 2010;45(11):472632.
24. Antre RV, Cendilkumar C, Goli D, Andhale GS, Oswal RJ. Microwave-assisted synthesis of novel pyrazolone derivatives attached to a pyrimidine moiety and evaluation of their anti-inflammatory, analgesic and antipyretic activities. Saudi Pharm J. 2011:19(4):233-43

25. Madhavi K, Sree RG. Synthesis, antioxidant and anti-inflammatory activities of ethyl 2-(2-cyano-3-(substituted phenyl)acrylamido)-4,5-dimethylthiophene-3carboxylates. Asian J Pharm Clin Res. 2017;10(7):95-100.

26. Aghekyana AA, Mkryana GG, Panosyana HA, Buniatyana GM, Muradyana RE. Synthesis and Antioxidant Activity of Ethyl 2-Amino-6-cyano-6-phenyl-4,5,6,7tetrahydro-1-benzothiophene-3-carboxylates and 3-Amino-4-oxo-7-phenyl3,4,5,6,7,8-hexahydro-benzo[4,5] thieno[2,3-d]pyrimidine-7-carbonitriles. Russ J Org Chem. 2020;56(3):440-5

27. Padmanabhan $P$, Jangle SN. Evaluation of the in-vitro anti-inflammatory activity of herbal preparation, a combination of four medicinal plants. Int J Basic App Med Sci. 2012;2(1):109-16.

28. Elias G, Rao MN. Inhibition of albumin denaturation and anti-inflammatory activity of dehydrozingerone and its analogs. Ind J Exp Biol. 1988:26(10):540-2.

29. Rashmi S, Prabhakar KV. Synthesis of thiophene derivatives and their antimicrobial, antioxidant, anticorrosion and anticancer activity. BMC Chem. 2019;13(1):54

30. Shailee VT, Nkalje APG, Deepak L, Aniket S. Synthesis, biological evaluation molecular docking study and acute oral toxicity study of coupled ImidazolyPyrimidine derivatives. Drug Des Dev Ther. 2018;15(5):475-87.

31. Vichai V, Kirtikara K. Sulforhodamine B colorimetric assay for cytotoxicity screening. Nat Protoc. 2006;1(3):1112-6.

32. Ramesh G, Janardhan B, Ranjith KT, Althaf HSK, Rajitha B. 3-(1-Phenyl-4-((2(4-arylthiazol-2-yl)hydrazono)methyl)-1 H-pyrazol-3-yl)-2H-chromen-2-ones: Onepot three-component condensation, in vitro antimicrobial, antioxidant and molecular docking studies. Nat Prod Chem Res. 2015;3:6.

33. Jahangir MA, Ozair A, Suroor AK, Javed MN, Mohammad I, Girdhar SD. Synthesis, anti-inflammatory, analgesic, COX1/2-inhibitory activity and molecular docking studies of hybrid pyrazole analogs. Drug Des Dev Ther. 2016;10:3529-43.

34. Ahmad FE, Ahmed OH, Rehab FAR, Ayman RB. Design, Synthesis, in vivo Anti-inflammatory, Analgesic Activities and Molecular Docking of Some Novel Pyrazolone Derivatives. Med Chem. 2015;5(10):458-66.

35. Mardia TS, Marwa AMS, Eman SZ, Nesrin MM, Ahmed RE, Andrey V, et al. Design, Synthesis, anti-inflammatory activity and Molecular docking of Potentia novel antipyrine and pyrazolone Analogs as cyclooxygenase enzyme (COX) Inhibitors. Bioorg Chem. 2018;76:188-201.

36. Mubarak HS, Dnyaneshwar DS, Bapurao BS, Firoz AK, Jaiprakash NS, Vijay MK et al. Synthesis, biological evaluation and molecular docking of novel coumarin incorporated triazoles as antitubercular, antioxidant and antimicrobial agents. Med Chem Res. 2016;25(4):790-804.

37. Gursoy A, Demirayak S, Capan G, Erol K, Vural K. Synthesis and preliminary evaluation of new 5-pyrazolinone derivatives as analgesic agents. Eur J Med Chem. 2000:35(3):359-64

38. Turan-Zitouni G, Sivaci M, Kiliç FS, Erol K. Synthesis of some triazolyl-antipyrine derivatives and investigation of analgesic activity. Eur J Med Chem. 2001;36(78):685-9.

39. Lutsevich AN, Bender KI, Reshet'ko OV. The relationship between antipyrine kinetics, the seromucoid content and the xanthine oxidase activity in the plasma of rats with acute and chronic inflammation. Eksp Klin Farmakol. 1995:58(4):51-5

40. Bondock S, Rabie R, Etman HA, Fadda AA. Synthesis and antimicrobial activity of some new heterocycles incorporating antipyrine moiety. Eur J Med Chem. 2008:43(10):2122-9

41. Metwally MA, Gouda MA, Harmal AN, Khalil AM. Synthesis, antitumor cytotoxic and antioxidant evaluation of some new pyrazolotriazines attached to antipyrine moiety. Eur J Med Chem. 2012;56:254-62.

42. Kakiuchi Y, Sasaki N, Satoh-Masuoka M, Murofushi H, Murakami-Murofushi K. A novel pyrazolone, 4,4-dichloro-1-(2,4-dichlorophenyl)-3-methyl-5-pyrazolone, as a potent catalytic inhibitor of human telomerase. Biochem Biophy Res Commun. 2004;320(4):1351-8.

43. Sigroha S, Narasimhan B, Kumar P, Khatkar A, Ramasamy K, Mani V, et al. Design, synthesis, antimicrobial, anti-evaluation and QSAR studies of 4-(substituted benzylidene-amino)-1,5-dimethyl-2-phenyl-1,2-dihydropyrazol-3-ones. Med Chem Res. 2012;21(11):3863-75.

44. Mojtahedi MM, Saeed MA, Peyman M, Mehdi A. Convenient synthesis of 2-aminothiophene derivatives by acceleration of gewald reaction under ultrasonic aqueous conditions. Synthetic Comm. 2010;40(14):2067-74.

45. Lipinski CA, Franco L, Beryl WD, Paul JF. Experimental and computationa approaches to estimate solubility and permeability in drug discovery and development settings. Adv Drug Deliv Rev. 2001;46:3-26.

Article History: Submission Date : 26-12-2020; Revised Date : 11-01-2021; Acceptance Date : 29-01-2021

Cite this article: Yasar Q, Zaheer Z. 4-Aminoantipyrine Analogs as Anti-inflammatory and Antioxidant agents: Synthesis, Biological Evaluation and Molecular Docking Studies. J Young Pharm. 2021;11(1):14-22. 